\title{
Effect of Different Feeding Frequency Employing Total Mixed Ration (TMR) on Dry Matter Intake and Milk Yield in Dairy Cows during the Winter
}

\author{
V. KUDRNA \\ Research Institute of Animal Production, Prague, Czech Republic \\ Received July 9, 2002 \\ Accepted September 22, 2003
}

\begin{abstract}
Kudrna V.: Effect of Different Feeding Frequency Employing Total Mixed Ration (TMR) on Dry Matter Intake and Milk Yield in Dairy Cows during the Winter. Acta Vet. Brno 2003, 72: 533-539.

The aim of the study was to study the effects of changes in feeding frequency of TMR $(2-1-$ 2 times a day) on milk yield and milk composition, feed and nutrient consumption, selected parameters of rumen liquid and rumination intensity (length and number of rumination periods). No significant differences in performance, rumen fluid indices and rate of rumination were detected. Similarly, differences in dry matter intake $(819.2 \mathrm{~g} / \mathrm{head} /$ day $)$ were non-significant $(P>$ $0.05)$. Results of the periodical experiment with 13 dairy cows fed once a day ad libitum during the winter season have shown that in stables with adequate conditions (capacity of feeding troughs, availability of feeds etc.) TMR to dairy cows may be fed once a day during the winter season without any unfavourable impact either on performance or health state of dairy cows, and the same milk yield as with feeding twice-a-day can be obtained.
\end{abstract}

Dairy cows, feeding frequency, DMI, milk yield, physiological indices

Optimum nutrition of dairy cows is the basic prerequisite for maintenance of their good health and full use of their milk yield capacity. The function of the digestive tract and utilization of feeds is also influenced by the feeding technique, among others by the feeding frequency during the day. It is a common practise to feed dairy cows twice a day. This fact contradicts the opinion that the more frequent feeding the higher the dry matter intake. However, there is also a conflict with the theory, that it is economically more advantageous to feed at minimal frequency and, in this way, to enhance labour productivity. The question of the feeding frequency of concentrates but also of TMR is still being solved. Especially the frequency of feeding concentrates, namely the dry matter intake (DMI), milk performance and indices of digestion in rumen have been studied. Gill and Castle (1983) compared the effect of feeding a protein concentrate twice, four times and 22 times during the 24-hr period. Feeding frequencies were not influenced by offering the feed at abovementioned intervals. Feed consumption, milk yield or live weight of dairy cows were not subject to changes. More frequent feeding increased milk fat concentration but the time of feeding and rumination was not affected. Kaufmann et al. (1980) followed the effect of feeding concentrates on $\mathrm{pH}$ values, concentration of volatile fatty acids and milk performance. McLe od et al. (1994) studied two different frequencies of feeding hay before and after feeding concentrates. Coherence among feeding frequencies, width of the feeding space at the manger and the number of animals per group was reported by Doležal (1998). Physiological problems as consequences of low concentrate feeding frequencies have been solved partly by using automatic feeding systems that dose the concentrates in feeding boxes and partly by using mixed feeding rations (TMR). A result of several portions of TMR is, according to McCullogh (1994), a uniform process of ruminal fermentation when DMI consumption increases. Better energy and nitrogen utilization, increase in milk fat content 
and fewer digestive problems resulted. Shabi et al. (1999) reported the results of feeding dairy cows twice and four times a day when organic substances differed in their digestibility and protein degradability. Two feeding frequencies, twice and three times a day, were compared by Kudrna et al. (2001). Three feeding regimens aimed at comparing of feeding concentrates and TMR twice or four times a day were investigated by Fan et al. (2002). They found that in terms of milk yield the most effective way of feeding concentrates was four times per day when roughage was fed ad libitum. The main aim of our experiment was to compare two feeding frequencies ( $2 \mathrm{x}$ vs $1 \mathrm{x}$ per day) on dry matter intake, quantity and composition of milk, indices of rumen liquid, live weight and rumination activities in dairy cows during the winter season.

\section{Materials and Methods}

In the winter season (from January to March) an experiment with 13 cows of Holstein and Czech Red Spotted breeds ( 7 primiparous and 6 multiparous cows) was carried out. The following variables were studied under two feeding frequencies: feed and nutrient intake (dry matter [DM], fat, crude fibre, nitrogenous substances, NEL, PDIE, PDIN, macro-elements), milk yield, milk composition (contents of fat, protein, lactose, somatic cells and urea were recorded), chemical indices of rumen liquid (contents of $\mathrm{NH}_{3}$, rumen volatile fatty acids [rVFA] and $\mathrm{pH}$ ) and rumination activity. Dairy cows, on average 144 days after calving, were included into a group given feed regularly twice a day (at 06:45 and 16:45 h) during the first and the third treatment period (control-CT), while they were given feeds only once a day (at 06:45 h) during the second treatment period (experimental - ET). Each period lasted for three weeks. The first week was the adaptation (preparation period - PP), when animals became used to the modified regime of feeding, and during the following two weeks (experimental period - EP) all examined values were recorded. Animals were given the feeding ration in the form of TMR (total mixed ration) ad libitum. The feeding ration was prepared and mixed in "Luclar" feeding wagon. The feeding ration (Table 1) was based on alfalfa and corn cobs plus leaves mixture (CCLM) silages and also contained a mixture for high-yielding dairy cows, oat ground whole plants silage (GWP), fresh draff (brewery grain), sugar beet pulp silage, soybeans extracted meal and whole wheat grain.

Table 1

Composition of feeding ration

\begin{tabular}{|l|c|}
\hline Feedstuffs & \% OF DM \\
\hline Alfalfa silage & 18.9 \\
\hline Corn silage & 3.6 \\
\hline Ground corn cob silage & 20.9 \\
\hline Ground oat plants silage & 8.3 \\
\hline Alfalfa hay & 5.4 \\
\hline Fresh draff & 3.7 \\
\hline Extracted soybean meal & 12.4 \\
\hline Wheat grain & 5.0 \\
\hline Production mixture & 21.8 \\
\hline
\end{tabular}

Cows were stabled in an experimental barn with loose housing and TMR was placed in troughs on tensometric scales. Dairy cows were milked twice a day and all data about the amount of milk were recorded daily during each experimental period. Samples of milk were taken four times in each experimental period, always at the time of morning and evening milking. Animals were weighed as soon as they left the milking parlour at the beginning (twice) and at the end (also twice) of each experimental period. Samples of rumen liquid from six selected animals were taken twice using a gullet probe during the first and the third treatment and four times in the second treatment always 2:30 hrs (morning), 6:00 hrs (noon) and 10:30 hrs (evening) after morning milking. The six selected cows were observed for their rumination frequency for $24 \mathrm{~h}$ once during the first treatment, and a group of 12 (the same six animals as in the first period and six other animals) during the third treatment for the same reasons, while in the second treatment the same 12 animals, as in the third treatment, were watched twice. Determination of contents of organic and ash matters were done in accordance with AOAC (1990), and the same for NDF and ADF was done in accordance with the methods of Goering and Van Soest (1970). Values of some selected parameters (the dry matter intake, milk yield and contents of milk components, $\mathrm{NH}_{3}$ of rumen liquid etc.) were determined according to Reisenauer (1970). 


\section{Results and Discussion}

During ET (feeding once a day) an average daily dry matter intake (DMI) of $20185 \mathrm{~g}$ was achieved. The average of the same parameter (DMI), but in the course of both CTs, was $19304 \mathrm{~g}$. That was why the intake of the most of other nutrients was also higher during the second treatment (Tables 2a, 2b). The difference in DMI by 891.2 was not significant

Table $2 \mathrm{a}$

The average nutrients consumption (g/head/day)

\begin{tabular}{|c|c|c|c|c|c|c|}
\hline \multirow{2}{*}{ Period } & \multicolumn{7}{|c|}{ Nutrients } \\
\cline { 2 - 7 } & DM & N-subs. & NEL (MJ) & crude fibre & PDIN & PDIE \\
\hline I. & 18539.4 & 3758.0 & 135.2 & 2848.7 & 2494.9 & 2208.3 \\
\hline II. & 20194.9 & 3857.7 & 147.4 & 3083.1 & 2580.7 & 2345.9 \\
\hline III. & 20498.1 & 3932.7 & 144.2 & 2909.1 & 2619.5 & 2307.9 \\
\hline (I. +III.)/2 & 19303.6 & 3824.6 & 139.9 & 2878.9 & 2539.1 & 2256.3 \\
\hline $\begin{array}{c}\text { Difference } \\
\text { II. - (I. +III.)/2 }\end{array}$ & 891.3 & 33.1 & 7.5 & 204.2 & 41.6 & 51.6 \\
\hline
\end{tabular}

Table $2 b$

The average nutrients consumption (g/head/day)

\begin{tabular}{|c|c|c|c|c|c|}
\hline \multirow{2}{*}{ Period } & \multicolumn{5}{|c|}{ Nutrients } \\
\cline { 2 - 6 } & ADF & NDF & Ca & P & Na \\
\hline I. & 3319.53 & 5509.99 & 227.18 & 102.39 & 24.94 \\
\hline II. & 3583.04 & 6157.70 & 197.84 & 93.26 & 18.66 \\
\hline III. & 3556.56 & 6045.64 & 209.90 & 93.05 & 18.21 \\
\hline (I. +III.)/2 & 3438.05 & 5777.82 & 218.54 & 97.72 & 21.56 \\
\hline $\begin{array}{c}\text { Difference } \\
\text { II. - (I. +III.)/2 }\end{array}$ & 144.99 & 379.88 & -20.7 & -4.46 & -2.92 \\
\hline
\end{tabular}

$(P>0.05$; standard errors [SE] of tested sets of data: $\mathrm{CT}=2.926, \mathrm{ET}=3.381)$. On the contrary, in the experiment of Kudrna et al. (2001) there was a significantly higher DMI $(P<0.05)$ when cows were fed three times a day than when they were fed only twice a day during the summer season. It could be explained by a different level of secondary fermentation of loaded feeds and also by the effect of high temperatures during the summer season.

DMI mentioned above within the second treatment made $3.27 \%$ of the body weight and was probably partly reduced because of using cows of the Czech Red Spotted breed and partly because of including seven primiparous cows. As Chamberlain and Wilkinson (1996) or Homolka (1998) reported DMI was lower in primiparous cows by 10-15\% compared with multiparous, with the same milk yield.

The effect of investigated feeding frequency on milk performance is shown in Table 3. Also the milk performance in our experiment was not significantly influenced $(P>0.05)$ by changes in feeding frequencies, but it was higher by $0.26 \mathrm{~kg} / \mathrm{head} / \mathrm{day}$, when the cows were fed once a day. The content of milk protein and fat was higher (by $0.07 \%$, and by $0.09 \%$, respectively) in both CTs, but the content of lactose was the same in all treatments. The increase of milk protein content (by $0.12 \%$ ) and milk fat content (by $0.19 \%$ ) during the transition from the first to the second treatment was rather distinct. The FCM production was higher by $0.63 \mathrm{~kg}$ within the EP. Gibs on's (1989) conclusion from results of 35 experiments was that if a more frequent feeding had any effects on the increase of milk performance and fat content, these effects were only minor. In the study of Nocek and Braund (1985) feeding frequencies once and four times a day 
Table 3

The average values of milk performance parameters

\begin{tabular}{|l|c|c|c|c|c|}
\hline \multirow{2}{*}{ Components } & \multirow{2}{*}{ Units } & \multicolumn{3}{|c|}{ Period } & \multirow{2}{*}{$\begin{array}{c}\text { Average } \\
\text { I.+III. }\end{array}$} \\
\cline { 2 - 5 } & & I. & II. & III. & $28.44[5.988]^{*}$ \\
milk & kg/day & 28.88 & $28.70[6.096]^{*}$ & 28.03 & $28.44 .61[5.602]^{*}$ \\
protein & kg/day & 26.58 & $27.24[5.914]^{*}$ & 26.64 & 26.61 \\
fat & $\%$ & 3.53 & $3.65[0.276]^{*}$ & 3.62 & $3.58[0.247]^{*}$ \\
lactose & $\%$ & 3.47 & $3.66[0.856]^{*}$ & 3.67 & $3.57[0.841]^{*}$ \\
\hline
\end{tabular}

* - standard error of evaluated sets of data (SE)

affected neither the DMI nor the milk performance, only dairy cows fed four times a day tended to a lower DMI and a higher milk performance compared with cows fed once a day. The minute improvement of performance in our experiment was probably connected with the non-significantly higher intake of nutrients when the cows were offered feeds once a day (Tables $2 \mathrm{a}, 2 \mathrm{~b}$ ). On the contrary, in the experiment during the summer season, in which Kudrna et al. (2001) followed similar goals, again in compliance with the nutrient intake, a higher milk performance (by $1.24 \mathrm{~kg} / \mathrm{head} / \mathrm{day}$ ) was achieved with the feeding frequency of TMR three times a day than with twice-aday feeding $(P<0.05)$. Contents of milk components increased in both experiments, in line with proceeding lactation.

The values of rumen fluid are shown in Table 4. The lowest values of $\mathrm{pH}$ in the second treatment were found during the noon sampling when a decrease of these values by 0.17 was found, compared to the morning sampling when this decrease was by 0.13 (concerning the average of both CTs). The pH values of 6.25 (ET) and 6.29 (the average of both CTs) decreased to the lowest level of the whole day at the noon sampling (6.08 and 6.16. respectively), whereas they rose again at the evening sampling to 6.19 and 6.30 . respectively). The lowest $\mathrm{pH}$ values, found at noon (6.02, 6.08 and others, see Table 4) were followed by the highest proportion of total rVFA - 171.83 (ET) and 164.45 (the average of both CTs) $\mathrm{mmol} / \mathrm{l}$.

Table 4

The average composition of rumen fluid ( $\mathrm{mmol} / \mathrm{l})$

\begin{tabular}{|c|c|c|c|c|c|c|c|c|}
\hline DAY/TIME & PERIOD & $\mathrm{pH}$ & acetic acid & propionic acid & butyric acid & valeric acid & total acids & $\mathrm{NH}_{3}$ \\
\hline \multirow{4}{*}{ morning } & I. & 6.24 & 81.44 & 41.27 & 15.56 & 6.22 & 144.49 & 17.59 \\
\cline { 2 - 9 } & II. & 6.25 & 68.62 & 44.22 & 15.80 & 6.34 & 153.73 & 15.42 \\
\cline { 2 - 9 } & III. & 6.35 & 82.97 & 41.75 & 14.91 & 6.00 & 145.63 & 12.88 \\
\cline { 2 - 9 } & average I. + III. & 6.29 & 82.20 & 41.51 & 15.24 & 6.11 & 145.06 & 15.23 \\
\hline \multirow{5}{*}{ noon } & I. & 6.02 & 94.38 & 49.51 & 17.43 & 8.11 & 171.83 & 17.73 \\
\cline { 2 - 9 } & II. & 6.08 & 92.77 & 47.78 & 17.19 & 6.70 & 164.45 & 18.77 \\
\cline { 2 - 9 } & III. & 6.30 & 84.76 & 42.83 & 16.92 & 6.56 & 151.07 & 15.51 \\
\cline { 2 - 9 } & average I. + III. & 6.16 & 89.57 & 46.12 & 17.17 & 7.34 & 161.45 & 16.62 \\
\hline \multirow{5}{*}{ evening } & I. & 6.21 & 79.22 & 40.64 & 14.50 & 6.43 & 140.78 & 16.66 \\
\cline { 2 - 9 } & II. & 6.19 & 87.79 & 43.72 & 15.96 & 6.42 & 153.77 & 16.90 \\
\cline { 2 - 9 } & III. & 6.39 & 82.86 & 40.80 & 15.24 & 6.01 & 144.91 & 15.18 \\
\cline { 2 - 9 } & average I. + III. & 6.30 & 81.04 & 40.72 & 14.87 & 6.22 & 142.85 & 15.92 \\
\hline
\end{tabular}

All the $\mathrm{pH}$ values found in our study were at the lower limits of recommended values (Jagoš 1985) and values of 6.02 and 6.08 were even below them. The probable cause of this phenomenon was the relatively high content of carbohydrates in the feed ration as the 
Table 5

The effect of feeding frequency on intensity of rumination in dairy cows

\begin{tabular}{|l|c|c|c|c|c|}
\hline \multirow{2}{*}{ Parameter } & \multirow{2}{*}{ Units } & \multicolumn{3}{|c|}{ Period } & \multirow{2}{*}{$\begin{array}{c}\text { Average } \\
\text { I.+III. }\end{array}$} \\
\cline { 3 - 5 } $\begin{array}{l}\text { Average time } \\
\text { of rumination }\end{array}$ & hrs/head/day & $06: 09: 00$ & $08: 14: 10$ & $07: 25: 25$ & $06: 59: 57$ \\
\hline $\begin{array}{l}\text { Average amount } \\
\text { of rumination periods }\end{array}$ & amount/head & 11.33 & 13.92 & 13.25 & 12.61 \\
\hline $\begin{array}{l}\text { Average length } \\
\text { of rumination period }\end{array}$ & min/head/day & $32: 34$ & $35: 31$ & $33: 37$ & $33: 18$ \\
\hline
\end{tabular}

concentrates made over $50 \%$ of dry matter and other feeds (sugar beet pulps silage, draff) did not have a character of forage.

More than $4 \mathrm{~kg}$ of DM from CCLM silage was added to the above-mentioned proportion of concentrates. The intensity of fermentation processes was considerable, namely during the noon hours. On the other hand, the level of $\mathrm{NH}_{3}$ was within the physiological limits. The differences among single treatments were not significant $\left(P>0.05\right.$, total contents of $\mathrm{NH}_{3}$ in CT and ET [after testing for a presence of extreme differences]: 16.112 and 16.849 [mmol/l], respectively SE of sets of CT and ET: 4.402 and 3.969, respectively). The differences in the contents of $\mathrm{NH}_{3}$ in rumen liquid, with the above mentioned feeding techniques, were also minimal and ranged in the middle of physiological limits. However, they were always higher (by $0.19-2.15 \mathrm{mmol} / \mathrm{l})$ when animals were fed once a day $(P>0.05)$.

When the food intake was investigated, we found that the dairy cows indeed made 49.42 daily visits of troughs during the period of twice-a-day feeding, and the time of the food intake during one visit of the trough was only 208.75 seconds, whereas during once-a-day feeding with 48.33 visits it was prolonged to $234.56 \mathrm{~s}$, i.e. by $25.81 \mathrm{~s}$ more. Generally, during $24 \mathrm{~h}$ of the day dairy cows fed for 02:41:54 h on twice-a-day feeding schedule, and an average daily intake of the same TMR was $39.98 \mathrm{~kg} / \mathrm{head}$, whereas in once-a-day feeding frequency the clear daily intake lasted for 02:57:55 $\mathrm{h}$ and the average daily intake of the same TMR was $41.64 \mathrm{~kg} / \mathrm{head}$. Dairy cows consumed, when given feeds twice a day ad libitum, $0.809 \mathrm{~kg}$ of TMR and $0.832 \mathrm{~kg}$ of TMR when fed once-a-day. It was 0.396 , and $0.422 \mathrm{~kg}$, respectively, of DM daily (the average content of DM in TMR was $48.95 \%$ ).

The longest continuous and considerable rumination activity was observed during the night, in the period roughly from 19:00 to 04:00 h. Duration of rumination during the day was again divided into two unequally long periods by the time round noon with limited activity: a longer morning and a shorter afternoon ones.

The average number of rumination periods with feeding once a day was 13.92 (the average duration of the rumination was $00: 33: 18 \mathrm{~h}, \mathrm{SE}=1.977$ ), and when the cows were fed twice a day, the number of rumination periods was non-significantly lower (by 12.61, SE = $1.976)(\mathrm{P}>0.05)$, with the average duration of the rumination period $00: 33: 18 \mathrm{~h}$. The total duration of rumination in the ET was 08:14:10, whereas it was 06:59:57 in CTs. The lower intensity of rumination in the stable during the first treatment could have been caused by the lower temperatures (from 5 to $8^{\circ} \mathrm{C}$ ). John s on et al. (1979) mentioned that in cold weather animals show a higher appetite but the utilisation of feeds was lower by $10 \%$, with possible effect of the rumination activity. Dulphy et al. (1994) found that if a silage is ground when preparing TMR, total DMI improved, but the time of rumination shortened at the same time. In our experiment chewing of $1 \mathrm{~kg}$ of DM took 20.46 minutes for twice-a-day feeding frequency, whereas it was 21.73 minutes with once-a-day frequency. From the different point of view - cows chewed up in average $48.87 \mathrm{~g}$ of DM during 1 minute when they were fed once-a-day whereas only $46.01 \mathrm{~g} / 1 \mathrm{~min}$ for the other feeding frequency. 


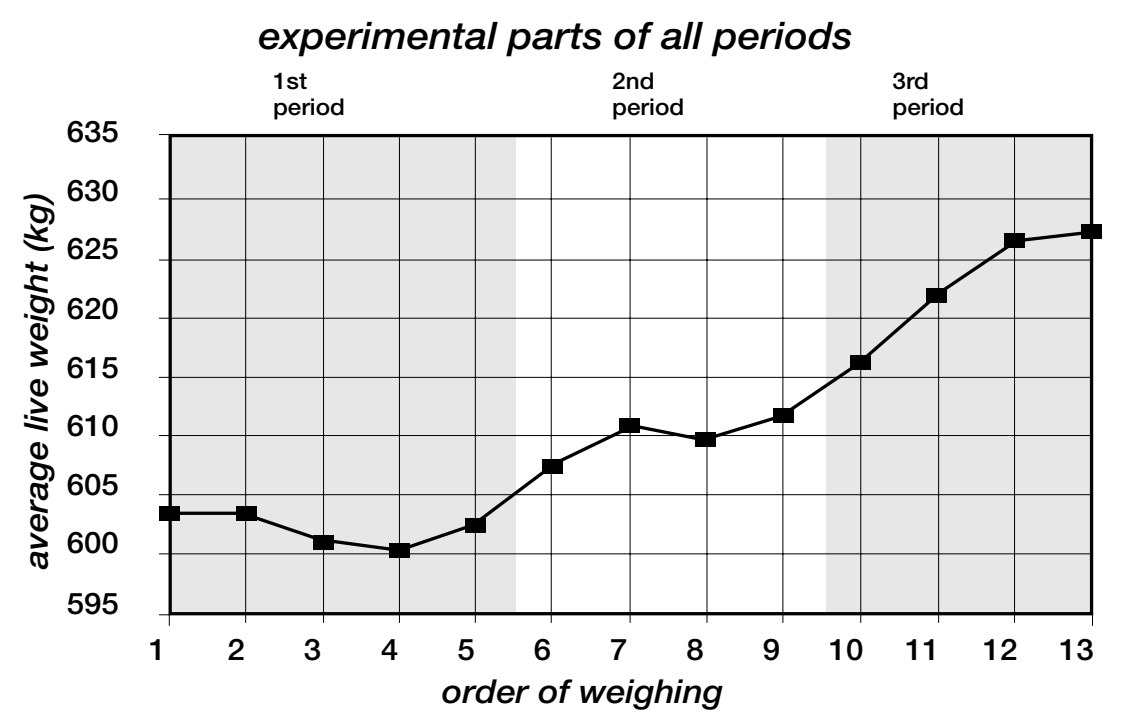

Fig. 1. The course of live weights changes

Dulphy et al. (1996) found that when concentrates were fed, the average time of rumination was $10 \mathrm{~min} / \mathrm{kg}$ of DM and when the roughage was fed it took $62.5 \mathrm{~min} / \mathrm{kg}$ of DM. The values which we have mentioned were taken if TMR was fed (thus including concentrates), where the structure of involved roughage was partly broken with technique of picking up from a storage. The course of changes of live weight is given in Fig. 1. From a shape of the curve it is apparent that the changes of live weights in all periods under study (two periods when cows were given feeds twice and one period with once-a-day feeding frequency) were roughly as expected.

In conclusion, the results of this experiment show that when animals are fed only once a day (ad libitum feeding), they may reach the same milk performance as with twice a day feeding. The results are supported by the evidence of physiological indices and intensity of rumination (length and number of rumination periods and their duration). Feeding once a day during winter in stables with proper conditions (above all the capacity of troughs, systematic heaping up of feed) enhances work productivity and improves farming economy.

\section{Vliv rozdílné četnosti krmení dojnic směsnou krmnou dávkou (TMR) na příjem sušiny a mléčnou užitkovost v zimním období}

Cílem pokusu bylo zjistit vliv změn frekvence krmení směsnou krmnou dávkou - TMR ( $2 \mathrm{x}-1 \mathrm{x}-2 \mathrm{x}$ denně) na mléčnou užitkovost, př́ijem krmiv a živin, složení mléka, vybrané parametry bachorových tekutin a intenzitu žvýkání. Výsledky periodického pokusu se 13 dojnicemi při krmení ad libitum dokládají, že při předkládání krmiv pouze 1x denně lze dosáhnout stejných výsledků $\mathrm{v}$ mléčné užitkovosti jako při krmení $2 \mathrm{x}$ denně. Ve sledovaných parametrech mléčné užitkovosti, bachorových tekutin a intenzity žvýkání nebyly zjištěny statisticky průkazné rozdíly. Zjištěné rozdíly v příjmu sušiny $(819.2$ $\mathrm{g} / \mathrm{ks} / \mathrm{den})$ byly rovněž statisticky neprůkazné $(P>0.05)$. Ve stájích s odpovídajícími podmínkami (kapacita žlabu, přihrnování krmiva atd.) lze v zimním období krmit dojnice směsnou krmnou dávkou pouze $1 \mathrm{x}$ denně bez nepříznivých dopadů na jejich mléčnou užitkovost nebo na zdravotní stav. 


\section{Acknowledgement}

This experiment was carried out as a part of a project of the Ministry of Agriculture of the Czech Republic No. QD 0176.

\section{References}

AOAC, 1990: Official methods of the Association of Official Analytical Chemists Methods. $15^{\text {th }}$ ed. AOAC, Washington DC

CHAMBERLAIN, AT, WILKINSON, JM 1996: Feeding the dairy cows, Chalcombe Publication.

DULPHY, JP, ROUEL, J, BONY J, ANDRIEU, JP, JAILLIER, M 1994: Feeding value of complete diets based on grass silage for dairy cows. Annals de Zootechnie 43: 113-123

FAN, YK, LIN, YL, CHIOU, PWS 2002: Effect of concentrate feeding frequency versus total mixed ration on lactational performance and ruminal characteristics of Holstein cows. Asian-Australasian J Anim Sci 15: 658-664

GIBSON, JP 1989: The effect of frequency of feeding on milk production of dairy cows, an analysis of published results. Anim Prod 38: 181-189

GILL, MS, CASTLE, ME 1983: The effects of the frequency of feeding concentrates on milk production and eating behavior in Ayrshire cows. J Anim Prod 36:79-85

HOMOLKA, P 1998: Systémy hodnocení energie a dusíkatých látek krmiv. In: Kudrna, V. et al.: Produkce krmiv a výživa skotu. Agrospoj, pp. 172-180

JAGOŠ, P et al. 1985: Diagnostika, terapie a prevence nemocí skotu. Praha, SZN

JOHNSON, CL 1979: The effect of level and frequency of concentrates feeding on the performance of dairy cows of different yield potential. J Agric Sci (Camb) 92: 743-751

KAUFMANN, W, HAGEMEISTER, H, DIRKSEN, G 1980: Adaptation to changes in dietary composition, level and frequency of feeding. pp. 587-602. In: Ruckebusch Y. and Thivend, P (Eds) Digestive physiology and metabolism in ruminants. MTP Press Ltd, Lancaster, UK

KUDRNA, V, LANG, P, MLÁZOVSKÁ, P 2001: Frequency of feeding with TMR in dairy cows in summer season. Czech J Anim Sci 46: 313-3319

MCCULLOUGH, ME 1994: Total mixed ration \& Supercows. $2^{\text {nd }}$ ed, WD: Howard \& Sons Co, Fort Ackinson, Wisconsin, USA

MCLEOD, GK, COLUCCI, PE, MOORE, AD, GRIEVE, DG, LEWIS, N. (1994): The effects of feeding frequency of concentrates and feeding sequence of hay on eating behaviour, ruminal environment and milk production in dairy cows. Can J Anim Sci, pp. 103-113

NOCEK, JE, BRAUND, DG 1985: Effect of feeding frequency on diurnal dry matter and water consumption, liquid dilution rate and milk yield in the first lactation. J Dairy Sci 68: 2238-2247

REISENAUER, R 1970: Metody matematické statistiky a jejich aplikace v technice. SNTL, Praha

SHABI, Z, BRUCKENTAL, I, ZAMWELL, S, TAGARI, H, ARIELI, A 1999: Effects of the synchronisation of the degradation of dietary crude protein and organic matter and feeding frequency on ruminal fermentation. Nutrient digestibility and milk yield and composition in dairy cows. J Dairy Sci 82: 1252-1260 